\title{
EFISIENSI BANK UMUM SYARIAH DI INDONESIA DENGAN PENDEKATAN THREE STAGES FRONTIER ANALYSIS
}

\author{
Ibnu Muttaqin \\ Univesitas Peradaban \\ Jl. Raya Pagojengan KM.3, Paguyangan, Brebes, Jawa Tengah 52276 \\ Email: ibnu.muttaqin@peradaban.ac.id
}

\author{
Rini Rini \\ Universitas Islam Negeri Syarif Hidayatullah Jakarta \\ Jl. Ir. H. Djuanda No. 95, Cempaka Putih, Ciputat Timur, Tangerang Selatan, Banten 15412 \\ Email: rini@uinjkt.ac.id
}

\author{
Alif Ilham Akbar Fatriansyah \\ STIE Al Madani Bandar Lampung \\ Jalan Kavling Raya Pramuka Rajabasa Bandar Lampung 35144 \\ Email: alifatriansyah@almadani.ac.id
}

\begin{abstract}
Efficiency is one of the parameters to measure the performance of the banking industry. This paper is using three stages to find out how the conditions of efficiency level of Islamic banking. Frontier and Stochastic Frontier Approaches are used to calculate the efficiency level and then averaged. Last, the determinants of efficiency were conducted by the Tobit Model. The data are 7 Sharia Commercial Banks during the period 2010 to 2017 which are chosen by purposive sampling. The study found the average efficiency level is $83.51 \%$ and is classified as less efficient. The Tobit model showed that all of the variables have not significant effect on efficiency level Islamic banking, except the ROA.
\end{abstract}

Keywords: Data Envelopment Analysis (DEA), Efficiency, Sharia Commercial Bank, Stochastic Frontier Analysis (SFA), Tobit Model

\begin{abstract}
ABSTRAK
Efisiensi merupakan salah satu parameter untuk mengukur kinerja industri perbankan. Makalah ini menggunakan tiga tahapan untuk mengetahui bagaimana kondisi tingkat efisiensi perbankan syariah. Pendekatan Frontier dan Stochastic Frontier digunakan untuk menghitung tingkat efisiensi dan kemudian dirata-ratakan. Terakhir, determinan efisiensi dilakukan dengan Model Tobit. Data yang diperoleh adalah 7 Bank Umum Syariah selama periode 2010-2017 yang dipilih secara purposive sampling. Hasil penelitian menemukan tingkat efisiensi rata-rata 83,51\% dan tergolong kurang efisien. Model Tobit menunjukkan bahwa semua variabel berpengaruh tidak signifikan terhadap tingkat efisiensi perbankan syariah, kecuali ROA.
\end{abstract}

Kata kunci: Data Envelopment Analysis (DEA), Efisiensi, BankUmum Syariah, Stochastic Frontier Analysis (SFA), Model Tobit 


\section{PENDAHULUAN}

Perbankan syariah, asuransi syariah, hingga pegadaian syariah yang biasa disebut sebagai Lembaga Keuangan Syariah (LKS) teus berkembang di Indonesia, namun perkembangannya belum menyamai sebaran dan pangsa pasar lembaga keuangan konvensional. Tentu saja hal ini butuh waktu dan tahapan yang panjang.

Tahun 1991 menjadi titik awal perjalanan ekonomi syariah di tanah air dengan beroperasinya Bank Muamalat Indonesia. Ekonomi dan industri keuangan syariah di Indonesia telah berjalan dua dekade lebih. Setelah masamasa awal yang lamban antara 1992-1998, industri keuangan syariah tumbuh secara signifikan dalam beberapa tahun terakhir ini (Fathony, 2015). Bermula dari tidak mendapatkan tempat dalam sistem perekonomian, sistem ekonomi syariah saat ini telah diakui sebagai sistem ekonomi alternatif di Indonesia (Amin, 2013).

Hingga dengan diberlakukannya Undang-Undang No. 21 Tahun 2008 tentang Perbankan Syariah, pengembangan industri perbankan syariah nasional semakin memiliki landasan hukum yang memadai dan semakin mendorong pertumbuhannya dengan lebih baik, ditunjang dengan adanya izin kepada Bank Konvensional untuk membuka kantor cabang Unit Usaha Syariah (UUS) dan melakukan spin off atau dengan konversi bank konvensional ke Bank Syariah.

Tabel 1. Pertumbuhan Pebankan Syariah di Indonesia Periode Tahun 2012 2018

\begin{tabular}{lccccccc}
\hline Kategori & 2012 & 2013 & 2014 & 2015 & 2016 & 2017 & 2018 \\
\hline BUS & 11 & 11 & 12 & 12 & 13 & 13 & 13 \\
\hline UUS & 24 & 23 & 22 & 22 & 21 & 21 & 21 \\
\hline BPRS & 158 & 163 & 163 & 163 & 164 & 167 & 168 \\
\hline \multicolumn{7}{r}{ Sumber : Otoritas Jasa Keuangan (OJK), 2018}
\end{tabular}

Berdasarkan data dari OJK, selama tahun 2011 hingga 2017 terjadi peningkatan pada besarnya Aset, Dana Pihak Ketiga (DPK) dalam hal ini adalah bagi hasil, dan Pembiayaan yang disalurkan oleh Perbankan Syariah. Tabel 2. Perkembangan Aset, Bagi Hasil dan Pembiayaan Perbankan Syariah di Indonesia Tahun 2012 - Juli 2018 (dalam Milyar Rupiah)

\begin{tabular}{lccccccc}
\hline & 2012 & 2013 & 2014 & 2015 & 2016 & 2017 & 2018 \\
\hline Aset & 195.018 & 242.276 & 272.343 & 296.262 & 356.504 & 424.181 & 431.427 \\
\hline Bagi Hasil & 147.512 & 183.534 & 217.858 & 231.175 & 279.335 & 334.888 & 339.195 \\
\hline Pembiayaan & 147.505 & 184.122 & 200.177 & 213.989 & 249.087 & 286.913 & 298.627 \\
\hline
\end{tabular}


Dari Tabel 2 dapat terlihat pertumbuhan perbankan syariah dari total aset pada Desember 2016 sebesar 356.504 Milyar Rupiah kemudian tumbuh menjadi 424.181 Milyar Rupiah pada 2017.

Hingga dewasa ini LKS sudah berkembang baik dan angka pertumbuhan ekonomi syariah secara nasional terlihat positif dengan capaian 20 persen dan berdasarkan data yang dihimpun Otoritas Jasa Keuangan (OJK) per Desember 2017, total aset pada sektor ekonomi syariah mencapai 424.181 miliar rupiah, namun sangat disayangkan antusiasme masyarakat untuk menggunakan jasa keuangan syariah masih berkisar pada 5,33\% dari keseluruhan pangsa pasar keuangan di Indonesia. Berdasarkan laporan Islamic Finance Country Index 2018, dari 48 negara yang disurvei, keuangan syariah Indonesia tahun 2018 menduduki posisi ke 6 setelah Malaysia, Iran, Arab Saudi, United Arab Emirates, dan Kuwait (Islamic Finance Country Index, 2018).

Industri keuangan syariah hingga kini sudah berkembang ke berbagai jenis industri keuangan syariah selain perbankan, seperti industri asuransi syariah dan pegadaian syariah, termasuk BMT dan Koperasi syariah yang tersebar di Indonesia. Untuk itulah, agar kinerja industri keuangan syariah semakin baik, salah satunya dengan pengukuran tingkat efisiensi.

Terkait kondisi real atas penuturan dari Direktur Bisnis Konsumer BNI Syariah yang termuat dalam laman Republika.com kami akses 20 Juni 2017, kondisi efisiensi perbankan syariah memang belum baik. Tingginya BOPO antara lain karena kualitas aset yang menurun, sehingga perseroan menyiapkan Cadangan Kerugian Penurunan Nilai (CKPN) lebih besar, penurunan aset masih dalam antisipasi perusahaan dan masuk dalam watchlist bank. Sementara itu, menurut sekretaris perusahan BSM, Dharmawan P Haddad mengatakan bahwa upaya yang dilakukan untuk meningkatkan efisiensi diantaranya peningkatan produktivitas, optimalisasi kinerja cabang, dan perbaikan end to end business process.

Menurut penuturan dari Direktur Utama BCA Syariah, John Kosasih, masih tingginya rasio BOPO perbankan syariah disebabkan industri ini tergolong masih baru dibandingkan konvensional dan belum mencapai skala yang ekonomis. Menurutnya, seiring dengan penggunaan teknologi yang semakin efektif ia menilai tingkat efisiensi perbankan syariah pun akan semakin meningkat, upaya yang dapat dilakukan di penghematan, dari transformasi ke digital, core banking, dan sebagainya. Ini adalah upaya yang tidak bisa dilakukan sesaat karena perkembangan yang sangat cepat, harus sustainable.

Khusus lembaga keuangan, pengukuran efisiensi (performance measurement) merupakan salah satu hal yang perlu dilakukan untuk mengetahui kinerja dari sistem lembaga keuangan tersebut, karena lembaga keuangan memiliki fungsi yang strategis dalam perekonomian. Oleh karena itu analisa efisiensi perbankan dan determinan atau faktor-faktor penentunya akan sangat bermanfaat bagi perekonomian suatu negara. Oleh karena itu analisis efisiensi perbankan akan sangat bermanfaat bagi perekonomian baik secara mikro (internal) maupun secara makro (ekternal) (Irawati, 2008). 
Tujuan utama dari penelitian ini adalah untuk mengetahui tingkat efisiensi perbankan syariah di Indoensia dan menganalisis faktor-faktor penentu yang berpengaruah terhadap tingkat efisiensi perbankan syariah di Indonesia. Pencapaian tujuan utama ini dilakukan melalui langkah-langkah: mengetahui tingkat efisiensi BUS di Indonesia menggunakan pendekatan DEA (Data Envelopment Analysis), mengetahui tingkat efisiensi BUS di Indonesia menggunakan pendekatan SFA (Stochastic Frontier Analysis), melihat apakah variabel aset, jumlah cabang bank, NPF, CAR dan ROA mempunyai pengaruh yang signifikan terhadap tingkat efisiensi perbankan syariah di Indonesia menggunakan model regresi Tobit.

\section{TELAAH TEORITIS DAN PENGEMBANGAN HIPOTESIS}

Kinerja keuangan bank merupakan bagian dari kinerja bank secara keseluruhan. Secara keseluruhan kinerja (performance) bank merupakan gambaran prestasi yang dicapai bank dalam operasionalnya, meliputi aspek keuangan, pemasaran, penghimpunan dan penyaluran dana, teknologi, maupun sumber daya manusia. Dengan demikian kinerja keuangan bank merupakan gambaran kondisi keuangan bank pada suatu periode tertentu baik menyangkut aspek penghimpunan dana maupun penyaluran dana yang biasanya diukur dengan indikator kecukupan modal, likuiditas dan profitabilitas (Abdullah, 2005).

Permasalahan pemanfaatan secara lebih baik dari setiap sumber daya yang telah diberikan, merupakan konsep dasar mengenai efisiensi (Shahid, 2010:25). Karim (2006) mendefinisikan "Efficient is doing the things right", yang berarti bahwa melakukan segala hal dengan cara yang tepat untuk mendapatkan hasil yang optimal.

Pembahasan mengenai efisiensi pada suatu Unit Kerja Ekonomi/perusahaan selalu mengenai bagaimana cara menghasilkan tingkat output yang maksimal dengan jumlah input tertentu, Farrell (1957). Dalam menggambarkan suatu kondisi tercapainya efisiensi dalam suatu perusahaan Farrell (1957) Farrel mengilustrasikan idenya dengan menggunakan sebuah contoh sederhana dengan kasus sebuah perusahaan tertentu yang menggunakan dua buah input ( $\mathrm{x} 1$ dan $\mathrm{x} 2$ ) untuk memproduksi sebuah output tunggal (q) dengan sebuah asumsi constant returnto scale (CRS).

Beberapa metode pengukuran efisiensi bank antara lain: a. Traditional Approach yaitu mengunakan Index Number atau Rasio, seperti Return On Asset/ROA, Capital Adequacy Ratio/CAR, Profitability Ratio. b. Frontier Approach: didasarkan pada perilaku optimal dari perusahaan guna memaksimumkan output atau meminimumkan biaya, sebagai cara unit ekonomi untuk mencapai tujuan. Pada pendekatan Frontier Approach dibedakan: 1. Deterministic Approach: sering digolongkan sebagai Pendekatan Non-Parametrik, pendekatan ini mengunakan Technical Mathematic Programing, atau populer dengan Data Envelopment Analysis/DEA. 2. Stochastic Approach: Pendekatan ini digolongkan sebagai 
pendekatan parametrik, menggunakan Econometric Frontier, salah satunya menggunakan Stochastic Frontier Analisys.

Pemodelan DEA berfungsi untuk mengukur tingkat efisiensi relatif suatu perusahaan dibandingkan dengan perusahaan sejenis. Pada dasarnya prinsip kerja model DEA adalah membandingkan data input dan output dari suatu organisasi data DMU (Decision Making Units) dengan data input dan output lainnya pada DMU yang sejenis. DEA merupakan pengembangan teknik pemograman linier yang di dalamnya terdapat fungsi kendala dan fungsi tujuan. Berikut adalah persamaan umum pada metode DEA.

$$
h_{s}=\frac{\sum_{i=l}^{m} u_{i s} y_{i s}}{\sum_{j=l}^{n} u_{j s} y_{j s}}
$$

Yang mana hs menunjukkan efisiensi teknis UKE s; uis menunjukkan bobot output i yang dihasilkan; yis adalah bobot input i yang diproduksi; vjs adalah bobot input $\mathrm{j}$; dan $\mathrm{xjs}=$ jumlah input $\mathrm{j}$ yang diberikan oleh UKE $\mathrm{s}$.

Sedangkan Stochastic frontier analysis (SFA) adalah salah satu teknik pengukuran efisiensi dengan pendekatan parametrik. Metode ini dikembangkan pada tahun 1977 oleh Aigner, Lovell, Schmidt serta Messen dan Van Broek (Hidayat, 2014). Pada metode ini, profit dari suatu bank dimodelkan untuk terdeviasi dari cost efficient frontier-nya akibat adanya random noise dan inefisiensi.

Nilai efisiensi dengan menggunakan metode ini adalah dalam bentuk prosentase. Semakin mendekati seratus persen menunjukan bahwa suatu bank bertindak semakin efisien dalam setiap periodenya.

Fungsi standar stochastic profit frontier memiliki bentuk umum (log) sebagai berikut :

$$
\operatorname{Ln} \mathrm{Ci}=\mathrm{f}(\ln \mathrm{Xji}, \ln \mathrm{Yki})+\mathrm{ei}
$$

Dimana :

$\mathrm{Ci}=$ Total biaya bank $\mathrm{n}$

$\mathrm{Xji}=$ Input $\mathrm{j}$ pada bank $\mathrm{n}$

Yji = Output $\mathrm{k}$ pada bank $\mathrm{n}$

ei $=$ Eror

ei terdiri dari 2 fungsi yaitu:

$$
\mathrm{ei}=\mathrm{ui}+\mathrm{vi}
$$

dimana :

$\mathrm{ui}=$ faktor eror yang dapat dikendalikan

$\mathrm{vi}=$ faktor eror yang bersifat random yang tidak dapat dikendalikan.

Diasumsikan bahwa $\mathrm{v}$ terdistribusi normal $\mathrm{N}(0, \sigma 2 \mathrm{v})$ dan $\mathrm{u}$ terdistribusi half-normal, $|\mathrm{N}(0, \sigma 2 \mathrm{v})|$ di mana uit $=(\mathrm{ui} \exp (-\mathrm{h}(\mathrm{t}-\mathrm{T}))$ dan $\mathrm{h}$ adalah parameter yang akan diestimasi.

Tobit dikemukakan oleh James Tobin pada 1958 ketika ia menganalisa pengeluaran para rumah tangga di Amerika Serikat untuk membeli mobil. Pengeluaran untuk mobil di beberapa rumah tangga menjadi nol (karena rumah tangga tersebut tidak membeli mobil), dan hal ini sangat berpengaruh terhadap hasil analisa regresi. Ia menemukan bahwa jika tetap menggunakan perhitungan OLS, perhitungan parameter akan cenderung 
mendekati nol dan menjadi tidak signifikan, atau jika menjadi signifikan, nilainya mengalami bias (terlalu tinggi atau terlalu rendah) dan juga tidak konsisten (jika ada data baru, hasilnya tidak sama atau tidak sesuai dengan hasil semula.

Bagan 1. Desain Penelitian

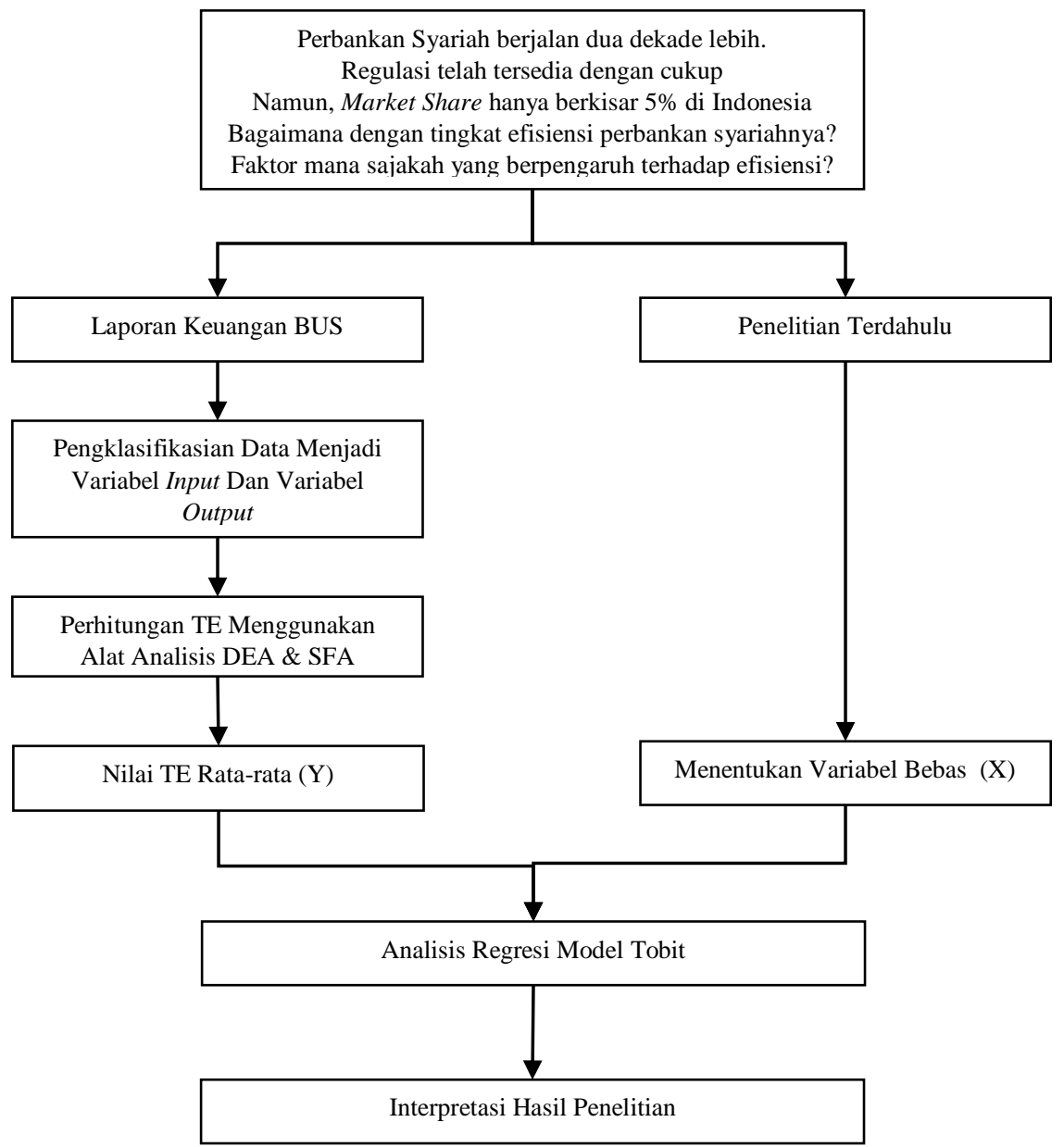

Metode Tobit mengasumsikan bahwa variabel-variabel bebas tidak terbatas nilainya (non-censured); hanya variabel tidak bebas yang censured; semua variabel (baik bebas maupun tidak bebas) diukur dengan benar; tidak ada autocorrelation; tidak ada heteroscedascity; tidak ada multikolinearitas yang sempurna; dan model matematis yang digunakan menjadi tepat. Dalam penggunaan metode analisis regresi untuk penelitian bidang sosial dan ekonomi, banyak ditemui struktur data yang mana variabel responnya mempunyai nilai nol untuk sebagian observasi, sedangkan untuk sebagian 
observasi lainnya mempunyai nilai tertentu yang bervariasi. Struktur data seperti ini dinamakan data tersensor (censored data), Endri (2008).

Model Tobit didasarkan pada model berikut :

$$
y_{i}=\left\{\begin{array}{c}
\beta^{\prime} x_{i}+u_{i}, \text { untuk } y_{i}>0 \\
0, \text { Selainnya }
\end{array}\right.
$$

Dimana y_i adalah peubah tak bebas, adalah vektor parameter berukuran $\mathrm{kx} 1$, xi adalah vektor regressor berukuran $\mathrm{kx} 1$, termasuk 1 bila dengan intersep, dan $\mathrm{u}$ adalah sisaan (galat) yang bebas dan berdistribusi normal dengan nilai tengah nol dan ragam $\sigma^{2}$.

Ismail, Shabri, dan Rahim (2013) melakukan penelitian tingkat efisiensi pebankan syariah dan konvensional di negara Malaysia, dalam penelitian ini telah diteliti juga faktor-faktor penentu efisiensi perbankan. Di Indonesia sendiri ada Faza dan Nadratuzzaman (2014) yang telah melakukan penelitian terkait efisiensi perbankan syariah sekaligus faktor penentunya pada BUS di Indoensia.

\section{METODE PENELITIAN}

Penentuan sampel yang digunakan dalam penelitian ini adalah purposive sampling. Tujuh Bank Umum Syariah yang penulis ambil karena memiliki aset yang besar dibanding BUS lainya, yaitu Bank BRI Syariah (BRIS), Bank BNI Syariah (BNIS), Bank Syariah Mandiri (BSM), Bank Muamalat Indonesia (BMI), Bank Mega Syariah Indonesia (BMS), Bank Syariah Bukopin (BSB), dan Bank Central Asia Syariah (BCAS). Ketujuh bank tersebut telah memiliki laporan keuangan dari tahun 2010 hingga tahun 2017.

Tahap pertama yakni ada dua variabel, yaitu variabel input dan variabel output, sedangkan variabel TC dibutuhkan untuk metode SFA. Meskipun tidak ada kesepakatan umum dalam pendekatan yang digunakan serta dalam hal menentukan input output, Berger dan Humprey (1997) dalam Muharram dan Purvitasari (2007) menyatakan bahwa pendekatan intermediasi merupakan pendekatan yang lebih tepat untuk mengevaluasi kinerja lembaga keuangan sebagai financial intermediation. Variabelnya yakni: Variabel Input: Bagi Hasil untuk Pemilik Dana Investasi sebagai P1, Variabel Input: Beban Tenaga Kerja sebagai P2, Variabel Output: Pendapatan Penyaluran Dana sebagai Q1, Variabel Output: Pendapatan Operasional Lainnya sebagai Q2, Variabel TC (Total Biaya) Untuk tahap perhitungan TE menggunakan SFA, terdapat variabel TC, adalah Total Biaya (Total Cost) yaitu penjumlahan dari (bagi hasil untuk pemilik dana investasi + beban estimasi kerugian komitmen dan kontinjensi + total beban operasional lainnya + beban penyisihan penghapusan aktiva + beban non operasional ) dibagi dengan total aktiva (Hidayat, 2014).

Variabel pada tahap selanjutnya atau yang kedua: Tahap ini hanya menghitung rata-rata tingkat efisiensi (TE) secara keseluruhan, yaitu setelah mendapatkan hasil TE dari metode SFA dan DEA dalam nilai prosentase dijumlahkan, kemudian dihitung rata-rata dari hasil kedua model teresebut, 
selanjutnya dijadikan sebagai variabel dependen secara kesatuan. Hasil efisiensi pada nantinya dapat dikelompokkan menjadi lima kategori dengan menggunakan pedoman di bawah ini (Azwar, 2012).

Tabel 3. Rumusan Kategori

\begin{tabular}{cc}
\hline Rumus Kategori & Kategori \\
\hline $\mathrm{X}<\mathrm{M}-1,5 \mathrm{SD}$ & Tidak Baik \\
\hline $\mathrm{M}-1,5 \mathrm{SD}<\mathrm{X}<\mathrm{M}-0,5 \mathrm{SD}$ & Kurang Baik \\
\hline $\mathrm{M}-0,5 \mathrm{SD}<\mathrm{X}<\mathrm{M}+0,5 \mathrm{SD}$ & Cukup Baik \\
\hline $\mathrm{M}+0,5 \mathrm{SD}<\mathrm{X}<\mathrm{M}+1,5 \mathrm{SD}$ & Baik \\
\hline $\mathrm{M}+1,5 \mathrm{SD}<\mathrm{X}$ & Sangat Baik \\
\hline
\end{tabular}

Keterangan :

$\mathrm{M}=$ Mean

$\mathrm{SD}=$ Standar Deviasi

Sedangkan variabel pada tahap ketiga yaitu menggunakan alat analisis regresi Tobit untuk meneliti pengaruh faktor-faktor penentu tingkat efisiensi. Variabel Dependen (Y) Dalam penelitian analisis Tobit ini, menggunakan skor efisiensi perbankan syariah (Y) yang diperoleh dari rata-rata perhitungan menggunakan alat analisis SFA dan DEA.

Variabel Independen $(\mathrm{X})$ yang akan digunakan tersebut ada lima, yaitu: Aset (X1), Jumlah Cabang Bank (X2), NPF (X3), CAR (X4), dan ROA (X5).

DEA pertama kali dikembangkan oleh Farreel (1957) yang mengukur efisiensi teknis satu input dan satu output menjadi multi input. Analisis DEA awalnya digunakan untuk mengatasi kekurangan analisis rasio dan regresi berganda, yang mana DEA dapat mengukur efisiensi dengan menggunakan input dan output lebih dari satu. Efisiensi suatu UKE adalah efisiensi suatu UKE dibandingkan dengan UKE yang lain yang menggunakan jenis input dan output yang sama (Sutawijaya dan Lestari, 2009). Efiesiensi dalam DEA adalah rasio dari total output tertimbang dibagi dengan total input tertimbang atau timbangan untuk setiap input dan output UKE (Muharram dan Purvitasari, 2007).

SFA disusun dari model eror dimana inefisiensi diasumsikan untuk mengikuti asimetri distribusi, biasanya half-normal, sementara random eror mengikuti simetris distribusi, biasanya standar normal. Ilmu mantiknya adalah bahwa inefisiensi harus memiliki truncated distribusi karena inefisiensi tidak bisa menjadi negatif. Inefisiensi dan eror diasumsikan menjadi orthogonal pada input, output, dan variabel lingkungan dispesifik dalam persamaan estimasi. Inefisiensi yang diestimasi untuk berbagai perusahaan diambil dari rata-rata kondisi atau model dari distribusi inefisiensi, memberikan observasi error term (Berger dan Humphrey, 1997).

Model regresi Tobit memang model yang paling banyak digunakan untuk variabel dependen yang bersifat censored sehingga model ini dikenal juga dengan istilah censored regression model (Gujarati, 2003). 


\section{HASIL DAN PEMBAHASAN}

Perhitungan efisiensi pada BRIS, BNIS, BSM, BMI, BMS, BSB, dan BCAS dengan metode DEA menggunakan empat variabel yang dibagi menjadi dua yaitu: hak pihak ketiga atas bagi hasil (bagi hasil untuk pemilik dana investasi) dan beban tenaga kerja sebagai variabel input, dan untuk variabel output adalah pendapatan pengelolaan (penyaluran) dana dan pendapatan operasional lainnya. Perhitungan ini dilakukan dengan software WINDEAP version 2.1 .

Tabel 4. TE BUS dengan Metode DEA (dalam persen)

\begin{tabular}{|c|c|c|c|c|c|c|c|}
\hline \multirow{2}{*}{ Tahun } & \multicolumn{7}{|c|}{ Nama Bank Umum Syariah } \\
\hline & BRIS & BNIS & BSM & BMI & BMS & BSB & BCAS \\
\hline 2010 & 71,6 & 100 & 89,1 & 100 & 83,9 & 75,7 & 97,1 \\
\hline 2011 & 69,9 & 99,7 & 83,1 & 91,4 & 90,8 & 74,8 & 96,6 \\
\hline 2012 & 82,7 & 100 & 96,3 & 89,8 & 100 & 85,5 & 87,1 \\
\hline 2013 & 79,2 & 75,4 & 94 & 92,4 & 100 & 88 & 84,5 \\
\hline 2014 & 80,4 & 73,6 & 83,3 & 88 & 80 & 89,5 & 85 \\
\hline 2015 & 85,6 & 81,1 & 75,7 & 83,9 & 90,2 & 93,2 & 100 \\
\hline 2016 & 89,1 & 84,8 & 78,5 & 71,6 & 100 & 89,6 & 100 \\
\hline .2017 & 83,4 & 97,7 & 85,7 & 71,9 & 97,2 & 78,2 & 88,5 \\
\hline
\end{tabular}

Untuk perhitungan metode SFA dilakukan dengan software Frontier versi 4.1. TE tersebut dianalisis menggunakan model fungsi biaya dengan variabel dependen total biaya (TC), dan variabel independen ada empat variabel terdiri dari dua input dan dua output sama seperti metode DEA.

Tabel 5. TE BUS dengan Metode SFA (dalam persen)

\begin{tabular}{cccccccc}
\hline \multirow{2}{*}{ Tahun } & \multicolumn{7}{c}{ Nama Bank Umum Syariah } \\
\cline { 2 - 8 } & BRIS & BNIS & BSM & BMI & BMS & BSB & BCAS \\
\hline 2010 & 82,7 & 79 & 80,5 & 23,2 & 81,5 & 82,8 & 80 \\
\hline 2011 & 80,6 & 81,2 & 80,9 & 83,8 & 80,1 & 81,8 & 79 \\
\hline 2012 & 80,6 & 80,9 & 80,6 & 85,1 & 79 & 81,7 & 79,2 \\
\hline 2013 & 80,8 & 79,5 & 79,8 & 84,3 & 83 & 82,9 & 78,1 \\
\hline 2014 & 79,9 & 86,3 & 80,2 & 83,1 & 83,5 & 82,4 & 81,4 \\
\hline 2015 & 72,9 & 78,2 & 79,2 & 82,0 & 96,1 & 39,3 & 79,2 \\
\hline 2016 & 90,0 & 81,3 & 79,8 & 81,8 & 81,4 & 83 & 82,0 \\
\hline 2017 & 79,1 & 81,8 & 80,4 & 85,2 & 83 & 82,8 & 80,5 \\
\hline \multicolumn{7}{c}{ Sumber : Data diolah } & \\
\end{tabular}


Perbedaan dari hasil perhitungan dari dua metode yang sama-sama menghitung tingkat efisiensi BUS dari tahun 2010 hingga tahun 2017 dapat dilihat pada Grafik 1 .

Grafik 1. Perbandingan TE BUS antara Metode DEA dan SFA Tahun 20102017 (dalam persen)

Sumber : Data Diolah

Dalam Grafik 1 tersebut perhitungan rata-rata TE menggunakan metode DEA selalu lebih tinggi dibandingkan dengan perhitungan TE menggunakan metode SFA, hanya berbeda yang terjadi pada BRIS untuk hasil TE metode SFA terhitung lebih tinggi dibandingkan dengan metode DEA, akan tetapi selisihnya hanya sedikit $0,6 \%$ saja. Jika dilihat untuk metode DEA rata-rata berada di atas angka $80 \%$ (tepatnya rata-rata $87,2 \%$ ) sedangkan metode SFA selalu berada di sekitar angka $80 \%$.

Kami sajikan pengelompokan nilai tingkat efisiensi rata-rata tiap-tiap bank, untuk mean didapatkan 83,51\% dengan standar deviasi sebesar 2,98, dan range kategori TE (Azwar, 2012) dapat dilihat pada Tabel 6.

Tabel 6. Pengkategorian Tingkat Efisiensi BUS

\begin{tabular}{cc}
\hline Skor Efisiensi & Kategori \\
\hline$<79$ & Tidak Efisien \\
\hline $80-82$ & Kurang Efisien \\
\hline $83-85$ & Cukup Efisien \\
\hline $86-88$ & Efisien \\
\hline$>88$ & Sangat Efisien \\
\hline
\end{tabular}

Sumber : Data Diolah 
Pengkategorian baik metode SFA, DEA, dan rata-rata dapat dilihat pada Tabel 7.

Tabel 7. Pengkategorian Tingkat Efisiensi BUS (Dalam Persen)

\begin{tabular}{ccccc}
\hline \multirow{2}{*}{ BUS } & SFA & DEA & \multicolumn{2}{l}{ Rata-rata } \\
\cline { 2 - 5 } & TE & TE & TE & Kategori \\
\hline BRIS & 80,83 & 80,24 & 80,53 & Kurang Efisien \\
\hline BNIS & 81,03 & 89,04 & 85,03 & Cukup Efisien \\
\hline BSM & 80,18 & 85,71 & 82,94 & Kurang Efisien \\
\hline BMI & 76,06 & 86,13 & 81,09 & Kurang Efisien \\
\hline BMS & 83,48 & 92,76 & 88,12 & Sangat Efisien \\
\hline BSB & 77,09 & 84,31 & 80,70 & Kurang Efisien \\
\hline BCAS & 79,93 & 92,35 & 86,14 & Efisien \\
\hline Rata-rata & 79,8 & 87,22 & 83,51 & Cukup Efisien \\
\hline
\end{tabular}

Dapat disimpulkan pada Tabel 7 bahwa pada metode SFA nilai tertinggi oleh BMS hanya terkategorikan cukup efisien, sedangkan BNIS, BRIS, BSM, dan BCAS tergolong kurang efisien, dan untuk BSB serta BMI tergolong tidak efisien. Sedangkan pada metode DEA untuk BCAS, BMS, dan BNIS, dikategorikan sangat efisien, sedangkan BMI tegolong efisien, untuk BSB dan BSM tergolong cukup efisien, lain halnya dengan BRIS masih dikategorikan kurang efisien.

Dari hasil rata-rata dari kedua metode tersebut dapat disimpulkan bahwa BRIS, BSM, BMI, dan BSB masih tergolong kurang efisien, BUS plat merah BNIS cukup efisien, untuk BCAS dapat dikgolongkan efisien, terakhir BMS paling unggul, mendapatkan kategori sangat efisien.

Langkah terakhir pada penelitian ini yakni dianalisis faktor-faktor penentu tingkat efisiensi Bank Umum Syariah menggunakan model Regresi Tobit, maka dari itu secara keseluruhan metode dalam penelitian ini disebut Three Stages Frontier Analysis.

Tabel 8. Perbandingan Analisis Faktor Penentu TE menggunakan Metode Tobit

\begin{tabular}{lrcrrrr}
\hline \multirow{2}{*}{ Variabel } & \multicolumn{2}{c}{ Metode SFA } & \multicolumn{2}{c}{ Metode DEA } & \multicolumn{2}{c}{ Rata-rata } \\
\cline { 2 - 7 } & $\begin{array}{c}\text { Z- } \\
\text { Statistic }\end{array}$ & Prob & $\begin{array}{c}\text { Z- } \\
\text { Statistic }\end{array}$ & Prob & $\begin{array}{c}\text { Z- } \\
\text { Statistic }\end{array}$ & Prob \\
\hline ASSET $\left(\mathrm{X}^{1}\right)$ & -0.396 & 0.692 & 1.728 & 0.084 & 0.36390 & 0.7159 \\
\hline CABANG $\left(\mathrm{X}^{2}\right)$ & 0.882 & 0.378 & -1.818 & 0.069 & 0.03504 & 0.9720 \\
\hline NPF $\left(\mathrm{X}^{3}\right)$ & -0.119 & 0.905 & 1.377 & 0.169 & 0.46656 & 0.6408 \\
\hline CAR $\left(\mathrm{X}^{4}\right)$ & 0.863 & 0.388 & -1.796 & 0.073 & 0.02738 & 0.9782 \\
\hline ROA $\left(\mathrm{X}^{5}\right)$ & 1.757 & 0.079 & 2.115 & 0.035 & 2.45896 & 0.0139 \\
\hline & \multicolumn{5}{c}{ Sumber : Data diolah } \\
\end{tabular}


Untuk analisis regresi Tobit menggunakan perangkat lunak Eviews versi 9. Hasil analisis menggunakan metode Tobit diaplikasikan untuk menyimpulkan berpengaruh atau tidak faktor-faktor yang sudah dijadikan variabel independen terhadap tingkat efisiensi BUS. Penulis tetap mengaplikasikan analisis dengan metode two stages melalui jalur SFA dan DEA, untuk kemudian baru akan dilakukan three stages, hal ini dilakukan agar dapat terlihat perbedaannya. Hasil dari perhitungan analisis regresi Tobit dapat dilihat pada Tabel 8.

Pada Tabel 8 dapat diketahui perbedaan antara hasil analisis Tobit melalui jalur SFA dan DEA. Pada metode DEA ada satu variabel yang memiliki pengaruh signifikan dan berhubungan positif yakni variabel independen ROA $\left(\mathrm{X}^{5}\right)$ dengan nilai probabilitas di bawah 5\% yakni sebesar 0.035 . Hasil melalui metode SFA, tidak ada satu variabel-pun yang memiliki pengaruh signifikan terhadap tingkat efisiensi perbankan syariah di Indonesia. Akan tetapi untuk variabel independen ROA $\left(\mathrm{X}^{5}\right)$ di jalur SFA bisa dikatakan memiliki nilai mendekati berpengaruh meskipun belum bisa dikatakan signifikan yakni sebesar 0,078 mendekati 0,05.

Hasil perhitungan model Tobit dari tingkat efisiensi rata-rata didapat variabel aset $\left(\mathrm{X}^{1)}\right.$ tidak memiliki pengaruh yang signifikan dikarenakan nilai probabilitas yang di atas 0,05 , sedangkan dengan Z-statistik yang benilai positif maka dapat disimpulkan semakin besar nilai aset yang dimiliki BUS akan semakin efisien BUS tersebut, sebab dengan jumlah aset yang besar suatu perusahaan dapat lebih leluasa menjalankan aktifitas operasionalnya dan dapat mencapai optimalisasi sumber daya yang dimilikinya. Bank yang memiliki aset yang besar juga akan lebih mudah mengadopsi teknologi baru yang dapat meningkatkan kinerja dan meminimalkan biaya. Hasil pada penelitian ini berbeda dengan penelitian yang dilakukan oleh Faza dan Nadratuzzaman (2014), dalam penelitian beliau, aset berpengaruh signifikan secara positif.

Untuk variabel selanjutnya yakni variabel jumlah cabang bank $\left(\mathrm{X}^{2)}\right.$, dapat dilihat tidak berpengaruh signifikan dengan Z-statistik yang positif. Ini bisa disebabkan tidak semua daerah di Indonesia memiliki karakteristik yang sama persis, BUS harus melihat lebih tentang pangsa pasar di daerah, dalam hal penambahan cabang bank atau pengurangan apakah akan meningkatkan aset atau justru malah membuat bank tersebut berada pada kondisi inefisien. Hasil pada penelitian ini tidak sama dengan penelitian yang dilakukan oleh Faza dan Nadratuzzaman (2014) dengan hasil signifikan serta negatif.

Berlanjut ke variabel bebas selanjutnya yakni NPF $\left(\mathrm{X}^{3}\right)$, menunjukan sebagai sebuah variabel yang tidak signifikan dalam pengaruh, hubungan secara positif terhadap tingkat efisiensi, dengan skor 0,6. Berbeda dengan hasil penelitian Faza, Nadratuzzaman (2014) yang menyimpulkan sebagai variabel yang berpengaruh secara negatif dan signifikan. Akan tetapi mirip dengan hasil riset Wahab (2015) yang menyimpulkan bahwa variabel NPF tidak signifikan pengaruhnya, dengan hubungan yang negatif..

Kemudian variabel keempat CAR $\left(\mathrm{X}^{4}\right)$ memperlihatkan hasil sebagai variabel yang tidak berpengaruh pula dengan korelasi positif. CAR adalah rasio yang harus diperhatikan perusahaan tetap pada standar minimal yang 
ada, yakni $8 \%$, untuk itu jika perusahaan dapat menjaga kestabilan nilai CAR tersebut maka tidak ada pengaruh yang berarti terhadap efisiensi perusahaan. Hal ini berbeda dengan penelitian Faza, Nadratuzzaman (2014) yang menunjukan hasil pengaruh signifikan secara negatif, namun sama dengan penelitian Wahab (2015) tidak terdapat pengaruh dengan korelasi positif.

Variabel pamungkas ROA sebagai $\mathrm{X}^{5}$, menjadi satu-satunya variabel yang secara signifikan berpengaruh dengan korelasi positif, bisa dikatakan ini sesuai dengan teori yang ada, yang menerangkan bahwa semakin tinggi keuntungan suatu perusahaan, maka perusahaan tersebut bisa dikatakan semakin efisien. Hasil pada penelitian ini juga sesuai dengan penelitian yang dilakukan oleh Faza, Nadratuzzaman (2014) yang menyebutkan return on asset berpengaruh signifikan dan positif. Akan tetapi pada penelitian Wahab (2015) menunjukan hal yang cukup berbeda yaitu tidak memiliki pengaruh yang signifikan, tapi pada Z-statistik menunjukan hal yang sama yaitu adanya korelasi positif.

\section{SIMPULAN}

Kesimpulan yang dapat kami utarakan Pertama, tingkat efisiensi pada Bank Syariah menggunakan metode Data Envelompent Analysis (DEA) dapat disimpulkan bahwa BRIS kurang efisien, BNIS Sangat efisien, BSM cukup efisien, BMI terkategorikan efisien, BMS tergolong sangat efisien, BSB cukup efisien, dan BCAS sangat efisien. Tingkat efisiensi seluruh BUS sampel tergolong efisien.

Kedua Untuk TE pada Bank Umum Syariah menggunakan metode Stochastic Frontier Analysis (SFA) untuk BRIS, BNIS, BSM, dan BCAS tergolong kurang efisien, dan untuk BMI serta BSB tergolong tidak efisien, nilai tertinggi oleh BMS hanya terkategorikan cukup efisien. Tingkat efisiensi rata-rata seluruh BUS masih terkategorikan kurang efisien, dengan skor yang lebih rendah dari metode DEA.

Ketiga Hasil perhitungan pengaruh faktor penentu tingkat efisiensi perbankan syariah di Indonesia, menggunakan metode regresi Tobit menunjukan bahwa variabel aset tidak memiliki pengaruh signifikan dengan hubungan positif, pada variabel jumlah cabang bank tidak berpengaruh signifikan dan korelasi positif, sedangkan, variabel ketiga NPF tidak berpengaruh signifikan secara positif, sedangkan variabel CAR sama saja, tidak berpengaruh signifikan dengan hubungan yang positif, dan variabel ROA adalah satu-satunya variabel yang berpengaruh signifikan dengan korelasi positif.

Kesimpulan di atas memberikan berbagai implikasi, Pertama secara praktis bagi pihak manajemen bank dapat meningkatkan kinerja keuangan dengan lebih baik berdasarkan variabel yang telah diteliti pada penelitian ini, dengan terus memperhatikan output dan input yang dianalisis pada penelitian ini. Bagi otoritas pemerintah dalam perbankan khususnya perbankan syariah, mengingat hasil dari kedua metode memiliki nilai yang berbeda, menurut peneliti perlu dibuatkan standar baku dengan merujuk terhadap metode yang 
telah dipilih mewakili tingkat efisiensi mengingat masing-masing metode memiliki kelebihan dan kekuarngannya.

Kedua secara teoritis bagi para civitas akademika pada penelitian selanjutnya peneliti kira perlu dikaji dengan menambah variabel baik variabel input maupun output selain yang diteliti pada penelitian ini, dan perlu pula pengembangan dengan memperluas variabel independen serta variabel dependen agar lebih akurat dan komprehensif dalam menentukan tingkat efisiensi suatu bank serta faktor-faktor yang menentukannya.

\section{DAFTAR PUSTAKA}

Abdullah, M. F. (2005). Manajemen Perbankan: Teknik Analisis Kinerja Keuangan Perbankan. Universitas Muhammadiyah Malang.

Al-Amri, K. (2015). Takaful Insurance Efficiency in The GCC Countries. Humanomics, 31(3), 344-353.

Al-Amri, K., Gattoufi, S., \& Al-Muharrami, S. (2012). Analyzing the technical efficiency of insurance companies in GCC. The Journal of Risk $\quad$ Finance, 13(4), 362-380. doi:https://doi.org/10.1108/15265941211254471

Amin, M. (2013). Pembaharuan Hukum Ekonomi Syariah. Serang: Yayasan An-Nawawi.

Azwar, S. (2012). Metode Penelitian. Yogyakarta: Pustaka Belajar.

Berger, A. N., \& Humphrey, D. B. (1997). Efficiency of Financial Institutions: International Survey and Directions for Future Research. European Journal on Operatinoal Research, 98(2), 175-212.

Endri. (2008). Efisiensi Teknis Perbankan Syariah di Indonesia. Finance and Banking Journal, 10.

Fathony, A. (2015). Manajemen Risiko Kontemporer Bank, Koperasi dan BMT. Jakarta: Yayasan Pendidikan Nur Azza Lestari.

Farrell, M. J. (1957). The Measurement of Productivity Efficiency. Journal of the Royal Statistical Society, 120(3), 254.

Faza, M. F., \& Nadratuzzaman, M. (2014). Efisiensi Bank Umum Syariah Menggunakan Pendekatan Two-Stage Data Envelopment Analysis. Buletin Ekonomi Moneter Dan Perbankan, 16(2), 167-188. http://doi.org/10.21098/bemp.v16i2.31

Gujarati, D. (2003). Ekonometri Dasar (Terjemahan). Jakarta: Erlangga.

Hidayat, R. (2014). Efisiensi Perbankan Syariah Teori dan Praktik. Bekasi: Gramata Publishing. 
Irawati, L. (2008). Pengukuran Tingkat Efisiensi Bank Umum Syariah di Indonesia dan Analisis Beberapa Faktor Penentu. Depok: Tesis S2 Pasca Sarjana Universitas Indonesia.

Ismail, F., Shabri, A. M., \& Rahim, R. A. (2013). Efficiency of Islamic and Conventional Banks in Malaysia. Journal of Financial Reporting and Accounting, 11(1), 92-107. doi:10.1108/jfra-03-2013-0011

IFCI. (2018). Islamic Finance Country Index. Retrieved from http://www.gifr.net/publications/gifr2018/ifci.pdf

Muharam, H., \& Pusvitasari, R. (2007). Analisis Perbandingan Efisiensi Bank Syariah di Indonesia Dengan Metode Data Envelopment Analysis (periode Tahun 2005). Jurnal Ekonomi Dan Bisnis Islam, II(3), 80-166.

Sutawijaya, A., \& Etty, P. L. (2009). Efisiensi Teknis Perbankan Indonesia Pascakrisis Ekonomi: Sebuah Studi Empiris Penerapan Model DEA. Jurnal Ekonomi Pembangunan, 10(1).

Wahab. (2015). Analisis Faktor-Faktor Syariah Di Indonesia Dengan Pendekatan Two Stage Stochastic Frontier Aproach (Studi Analisis di Bank Umum Syariah). Jurnal Pemikiran Dan Penelitian Ekonomi Islam, VI(2), 57-76. 
